\title{
The Piano Music of Maurice Ohana
}

\author{
by Caroline Rae
}

\begin{abstract}
A composer whose first works date from his early thirties and whose first important, large-scale composition does not appear until the age of thirty-seven could well be perceived as a late starter. This to some extent was the case with Maurice Ohana. The earliest works which he allowed to remain in his catalogue were composed towards the end of the Second World War when, taking advantage of his army posting to Italy, he enrolled in the piano class of Alfredo Casella at the Academia Santa Cecilia in Rome. ${ }^{1}$ Ohana's first large-scale work, the setting of Federico García Lorca's Llanto por Ignacio Sanchez Mejias for baritone, narrator chorus and orchestra, followed some years later being completed, and receiving its first performance, in 1950. Although he established his compositional presence later than most others belonging to that illustrious generation of composers born in and around 1913, it would be misleading to suggest that Ohana either came to music late in life or was to any extent a late developer. ${ }^{2}$ His real beginnings as a composer were delayed not only by the Second World War, but by the success of his first career as a concert pianist which he pursued throughout the 1930s and for some time after his war service. It is not surprising, therefore, that music for his own instrument, the piano, should figure prominently in Ohana's catalogue. Indeed, much of his compositional development is reflected through his work in this medium, his music for solo piano spanning almost all of his creative years from the mid 1940s to the mid 1980s.
\end{abstract}


Although it is the intention of the present article to focus attention primarily on the works for solo piano, this instrument is also conspicuous in a significant number of Ohana's instrumental ensembles, sometimes playing the role of a quasi-soloist, as in Tombeau de Clande Debussy and Signes, at other times simply underpinning much of the overall texture, as in Lys de Madriganx and his last completed work Avoaha. 'Table I' combines the list of solo works (shown emboldened) with those in which the piano is used within an instrumental ensemble and shows the prominence of the instrument throughout the six decades of Ohana's composing life. In this context, the importance of the piano as a compositional tool should not be underestimated, not only as a source of certain characteristic gestures but as a medium of new harmonic resource achieved through the relatively simple means of tactile discovery. In interviews, Ohana was often proud to assert that his preferred process of composition was at the piano, explaining that he was able to 'discover' his own music through the pure joy of his beloved Steinway Model ' $\mathrm{D}$ ' which dominated his small Parisian apartment of the 16e arrondissement. The bitonality of Petrushka is one of the traditional examples of such pianistic approach to composition, but one can also consider some passages, albeit arguably less dramatic, in Scarbo from Ravel's Gaspard de la Nuit, composed three years earlier than the example of Stravinsky. ${ }^{3}$ Ohana's own model, had he needed to have one, would more characteristically have been drawn from Debussy whom he liked to consider as his spiritual and musical father. The essentially pianistic juxtaposition of black and white keys is easily found in Debussy who also is known to have composed at the piano: "Il n'y a pas de théorie! Suffit d'entendre. Le plaisir est la règle."4 


\section{TABLE I}

Dates given are those of completion. Withdrawn/Destroyed work $s+$. Unpublished works *

\section{DATE TITLE}

1940 Suite +

1944 Enterarr y Callar

1945 Sonatine Monodique

1947 Sarabande +

Deux Mélodies de Lorca +

1948 Paso

Duo for violin \& piano +

1951 Les Réprésentations de Tanit +

Suite pour un mimodrame +

1954 Hommage à Luis Milan

1954 Cantigas

1956 Images de Don Quichotte *

Le Guignol au Gourdin +

Prométhée +

1958 Le Récit de l'An Zéro *

1960 La Blessure *

La Route qui poudroie *

1961 Histoire véridique de Jacotin *

1962 Tombeau de Claude Debussy

1964 Les Héraclides *

1965 Iphigénie en Tauride *

Neumes

Signes

\section{DESCRIPTION}

solo piano

solo piano No.1 Trois Caprices

solo piano

two pianos

voice, piano (arr. voice \& guitar /

harpsichord)

solo piano No.3 Trois Caprices

ballet, orchestra (piano

transcription)

chamber orchestra

solo piano No.2 Trois Caprices

chorus \& instrumental ensemble

incidental music for instrumental

ensemble

music theatre, voices, instrumental ensemble

ballet, orchestra

chorus, instrumental ensemble

film music, instrumental

ensemble

incidental music for instrumental ensemble

music theatre,voices, instrumental ensemble

soprano, zither, piano \&

orchestra

incidental music for instrumental ensemble

incidental music for instrumental ensemble oboe \& piano

flute/piccolo, zithers, percussion \& piano 
1966 Hippolyte *

Synaxis

1967 Syllabaire pour Phèdre

1970 Sorôn-Ngô

" Syrtes

1971 Autodafé _

197324 Préludes

1974 T'Hâran-Ngô

" Office des Oracles

1975 Noctuaire

1976 Anneau du Tamarit

“ Lys de Madrigaux

1978 Trois Contes de l'Honorable Fleur

1979 Livre des Prodiges

1981 Concerto pour Piano et orchestre

1982 Etudes d'Interprétation I i-vi

1983 Etudes d'Interprétation II II xi \& xii incidental music for instrumental ensemble

(concerto) two pianos

percussion \& orchestra

chamber opera

two pianos

cello, piano

chamber opera, instrumental

ensemble

solo piano

orchestra

3 choruses, instrumental

ensemble

cello \& piano

concerto for cello \& orchestra

female chorus, instrumental

ensemble

music-theatre,soprano

instrumental ensemble

orchestra

piano concerto

solo piano

piano \& percussion

1985 Etudes d'Interprétation II vii-x solo piano

“ Kypris

1988 La Célestine

1990 Mariage sous la mer

1991 Avoaha

oboe,viola, double bass, piano

opera

children's opera

mixed chorus \& piano

A feature not shown on 'Table $I$ ' is the significant number of works which include the harpsichord as an integral member of many of Ohana's instrumental ensembles. While he may well have been attracted to this instrument for its obvious textural, Iberian associations as in the Llanto, Guignol au Gourdin, Images de Don Quichotte, the opera La Célestine and many others, it may also have been Ohana's particularly keyboard-oriented compositional approach which results in this instrument appearing in the very un- 
Spanish chamber opera, Syllabaire pour Phèdre of 1968. Ohana has made a significant contribution to the repertoire of the twentieth century harpsichord revival of the post-war years, his solo works for this instrument including a five movement concerto, Chiffres de Clavecin, also of 1968.

With Ohana's instinctive alignment towards French music, and particularly Debussy, in mind, some consideration should here be given to the composer's cultural background as this is often a source of confusion for those not well acquainted with Ohana's music. André Gide once wrote that Ohana was a "French Joseph Conrad", as like the Ukrainian-born Pole, his cultural identity did not correspond with his bureaucratic nationality. ${ }^{5}$ Although born in north Africa, in Casablanca, Maurice Ohana stemmed from Sephardic and Christian lineage. His father Simon David Ohana was a Gibraltan Andalusian (hence the close British affiliations) and his mother Fortuna Mercedes Rengio Ohana was of Castillian Spanish origin. The family surname (far from being Irish as many Anglo-Saxons assume) originates from a village approximately twenty miles north west of Almeria in Andalusia. It is however, a mistake to equate Ohana's music only with his Spanish origins; his education and upbringing in an entirely French speaking environment proved to be an immensely powerful influence. During the time he lived in Casablanca, Morocco was still under French control, indeed he took a baccalaureate in philosophy at a Lycée named after the French resident General of Morocco, Maréchal Lyautey. Following three years at the Bayonne Conservatoire from 1927 to 1931, he moved to Paris, initially to study architecture at the Ecole des Beaux Arts, but chiefly to continue his piano training and develop his musical career. He enrolled at the Schola Cantorum in 1937 where he studied with Daniel-Lesur until 1940 when hostilities required that he join the British Army. He returned to Paris after demobilisation in 1946, where he settled permanently. Not only was his return to the French capital a logical outcome of his education and upbringing, but like many Spanish artists and musicians, Ohana was required to emigrate northwards to exploit 
his cultural heritage. The significance of spending most of his early life on the Atlantic coast is also one which the composer himself considered important, not only for its historical associations but for its shaping on his personality. He described Atlantic Andalusians as quite different from those of the Mediterranean side; one looks eastwards in what he called 'chlostrophobic smallness', while the other is 'broad and expansive'. ${ }^{6}$ Even after settling in Paris, Ohana maintained a second home near Carnac in Brittany. This was the site he chose for his final resting place; his ashes were cast along this Atlantic coast.

"I don't appreciate very much the Mediterranean, I think that physically I don't belong to the Mediterranean at all..... of course I descend from the Mediterranean civilisation but I think it is very important that one should be faithful to one's geographical roots. I was born on the Atlantic and I find myself much more at ease with the Atlantic landscape and the Atlantic storms and its sunny days, than in the Mediterranean which is a very restrained field of experience to me. In my seaside house in Brittany when I watch the skies and the sea they convey a sort of permanent lesson, a permanent teaching which concern music just as much as ordinary living, be it only through the enormous proportions of the Atlantic compared to the Mediterranean."7

Ohana's outstanding pianistic gifts were recognised during his early childhood years when his family still lived in Casablanca. ${ }^{8}$ Following his first lessons at the age of five, he gave his first public recital at the age of eleven for a St. Cecilia's Day Concert at the Convent of Franciscan Missionaries in Casablanca with a programme including Chopin's Study Op.10 No.5 and the Beethoven 'Pathétique' Sonata Op.13. He has recounted some of his earliest childhood memories as being those of hearing many works of Chopin, Albeniz and Debussy played by his older sisters, one of whom, Naomi, was contemplating a professional performing career.' Although Ohana's first twelve years were spent in Morocco, where he was able to hear much of the indigenous music of the Berbers, his family returned regularly to Spain, spending summers in Grana- 
da or the Basque Country. When they moved to Biarritz in 1927, both Maurice and his sister Naomi enrolled at the Bayonne Conservatoire, studying with the Director Ermand Bonnal. By the time Maurice Ohana completed his training there in 1931, he had performed all thirty-two Beethoven sonatas. ${ }^{10}$ While this does not reflect what was to emerge as Ohana's preferred aesthetic domain, such a feat is certainly testimony to an outstanding technical and musical achievement. Moving to Paris in 1932 and vehemently opposing his father's desire to enter the so-called more respectable profession of an architect, Ohana studied with Lazare-Lévy who encouraged him to enter the piano class of the Paris Conservatoire. Due to his father's constraints, however, Ohana never did. From this time he began to give regular recitals which already revealed some of the individuality of his musical tastes. His programmes always included a significant proportion of works by Scarlatti, Chopin, Albeniz and Granados, while French music was represented by Rameau, Debussy and Ravel. He gave his Paris début recital in February 1936 at the Salle Debussy in the Salle Pleyel. Of mammoth proportions his programme clearly indicates Ohana's cultural alignment:

$\begin{array}{ll}\text { Scarlatti } & 3 \text { Sonatas } \\ \text { Chopin } & \text { Barcarolle,Polonaise-Fantasie, F minor Ballade } \\ \text { Debussy } & \text { L'Isle Joyeusc, Bruyères, Poissons d'Or } \\ \text { Granados } & \text { La Maja y el Ruissor } \\ \text { Ravel } & \text { Sonatine } \\ \text { Albeniz } & \text { El Puerto, Rondeña, Triana, El Albaicin }\end{array}$

This recital was followed by another at the Salle Chopin and concerto appearances with Eugène Bigot and the orchestra of the Concerts Lamoureux, performing most notably Nuits dans les Jardins d'Espagne. After studying for four years with Lazare-Lévy, Ohana decided to change teachers and took lessons instead from Frank Marshall and occasionally also from Artur Rubinstein. Finding this a more rewarding arrangement, he began to tour professionally, giving recitals in Holland, Belgium, Spain, north Africa as well as 
in France. He founded a two-piano duo with Alexandre Hoffstein and later also with Daniel-Lesur, as well as with the singer Lotte Schöne with whom he gave a European tour during the 1936-37 season. Following a chance meeting on the crossing of the Straits of Gibraltar between north Africa and Spain, he performed several times with the Flamenco singer and dancer 'La Argentinita' (Encarnación Lopez Julvez) and guitarist Ramón Montoya, both of whom had been close members of Federico Garcia Lorca's circle and involved in the 1922 Cante Jondo Competition at Granada with Manuel de Falla. In the late 1940s he also performed in London's Wigmore Hall and recorded for the BBC's Third Programme. Resulting from Ohana's association with André Gide he collaborated on the Notes sur Chopin, preparing all the musical examples. Gide and Ohana also planned a series of radio programmes on Chopin, but these unfortunately were later abandoned. " Even long after Ohana had devoted his energies fully to composition he maintained a close interest in the careers of young performers, receiving them for consultations at his home and serving as President of the jury for the International Debussy Competition (1979-1984). A biennial Ohana Prize has been founded since the composer's death in 1992 and is to be awarded to pianists and composers, alternately.

Among the generation of composers writing after the second world war, Ohana was one of the first to consider the new serial developments of his contemporaries a cul-de-sac, describing the post-Webernian cult as a 'false revolution' which closed more avenues than it revealed. ${ }^{12}$ Even in his very earliest piano works, the Trois Caprices and Sonatine Monodique, his compositional approach clearly illustrates his independence from predominant, contemporary trends. He has since frequently expressed an almost, iconoclastic rejection of all pre-compositional systems: "mere academic sterility but as intimidating and terrifying as the propaganda systems of Nazi Germany... These systems destroy more in music than they create - they remove all the art of risk."13 Ohana considered the so-called new techniques, hailed by Boulez as 'The 
Threshold' in Die Reihe, implicitly to represent a virtual cultural domination of southern musical cultures by northern Austro-German musical traditions. ${ }^{14}$ Ohana's conscious distancing of himself from composers involved at Darmstadt resulted in some isolation during his early years and a consequent exclusion from representation in the concerts of the Domaine Musicale. In order to assert his independence during the late 1940s, he founded a rival group of composers who shared his views and promoted their compositional non-conformism through performances of their own music. ${ }^{15}$ The sympathy of Henri Dutilleux to the aims of Le Groupe Zodiaque, as they came to be known, enabled the group to broadcast many of their concerts on the ORTF where Dutilleux was director of music productions at the time. Dutilleux, however, did not join the group. (Ohana later dedicated Tombeau de Claude Debussy to Henri Dutilleux). While remaining adamant in their rejection of all compositional schools, the aims of the Groupe Zodiaque were to emerge as the basis for Ohana's own musical language. In seeking to restore what they considered to be a true line of development from their respective cultural origins, the Zodiaque composers promoted the study of their own folk-musics, plain-song and much of the vocal repertoire of the 14 th and 15 th centuries. For Ohana, who was already well-acquainted with much of the early polyphonic vocal repertoire through his training at the Schola Cantorum, this meant a deeper investigation into the vocal and instrumental forms of the classical Flamenco and Andalusian Cante Jondo, as well as into the tribal music of the north African Berbers and black Africans, all familiar to him from his earliest childhood. He has described these sources as seminal influences: "My writing was built entirely upon plainchant and by meditating and observing my own folk-music."'l6

The Austro-German tradition was therefore quite irrelevant to Ohana's compositional preoccupations. His Iberian origins became a compositional catalyst as the immediate result of Ohana's researches was the appearance during the 1940s and 1950s of works revealing chiefly Spanish origins of which the Trois Caprices and Sonatine Monodique for solo piano are early examples. Although 
composed as separate pieces over a period of ten years (1944-54), the Trois Caprices combine to form a remarkably coherent whole and are far more indicative of the subsequent way in which Ohana's musical language was to develop than many other works of his early period. They also represent the first of a number of Ohana's works to draw inspiration form the nightmarish, surreal images of the Spanish painter Goya. The title of Ohana's triptych is taken from Goya's collection of Caprichos. It is perhaps not surprising that at the outset of his compositional life Ohana should return to images from his own cultural background which had already affected him deeply: "I knew Goya from childhood. I have always been haunted by Goya, his drawings, his paintings, but especially his general attitude to society..." All three of Ohana's Caprices echo the predominantly sombre and austere tragedy of Goya's engravings. Through a rediscovery of Goya, Ohana finds a ready-made representation of social organisation disintegrating into a soulless moral decay, this itself serving as a mirror to some of his own experiences at the time. The first of the Trois Caprices, 'Enterrar y Callar' ('Bury them and say nothing'), composed in 1944 while Ohana was enrolled in Alfredo Casella's piano class in Rome, borrows its title from one of Goya's 'Disasters of War', this particular engraving depicting a gruesome pile of mutilated dead bodies. The prevailing atmosphere throughout this short piano piece is one of unrelenting, desolate melancholy which in many ways is not unlike that evoked by Falla in his Homenaje Le Tombeau de Claude Debussy for guitar. The intimacy of the respective solo instruments in both of these pieces reflects the outpouring of a personal grief. In the case of Ohana this may well reflect his war-time experiences, and his association with the particular drawings of Goya, themselves depicting horrors of war, makes this connection almost unavoidable. Like Falla's Homenaje there are certain repetitive rhythmic patterns which characterise the piece; here, the rhythm of a slowed-down sarabande and a melodic motif of syncopated, tolling quavers. These features permeate the whole of 'Enterrar y Callar' and recall the repeated notes and melancholic atmosphere of both 'Le Gibet' of 
Ravel and Messiaen's prelude Cloches d'Angoisse et larmes d'adieu , although it is unlikely that either of these pieces served in any way as models for Ohana. Like the Ravel, however, which is Très lent, 'Enterrar y Callar' is Lento sostemuto and predominantly piano or pianissimo. It is the melodic material of the opening (Figure 1) which outlines the rhythmic features of a sarabande with its dotted rhythm and emphasis of the second beat, although here it is extended into a $6 / 4$, rather than the $3 / 4$. (Advantage is taken of the rhythmic ambiguity between compound duple and simple triple meter inherent in the 6/4.) This pattern also appears in Ohana's Tiento for guitar (1957), another piece of a similarly reflective, melancholic character. Another important feature in 'Enterrar y Callar' is the appearance of sudden, subito fortissimo melodic interpolations which may suggest the Andalusian Saeta, a spontaneous eruption of sentiment, either sung or played on the trumpet, occurring in the processions of Holy Week in Andalusia. The formal scheme in this first Caprice, like many of Ohana's forms, is sectional but continuous and unified by the periodic recurrence of the opening material. While Spanish in compositional genesis and musical reference, the pianistic texture is far closer to French rather than Austro-German traditions. There is much use made of pedal notes or chords underpinning the melodic lines and a clear distinction between the use of both sostemuto and sostenente pedals, as well as passages intended to be without pedal.

Composed in 1945 immediately after 'Enterrar y Callar', the Sonatine Monodique was intended primarily as a compositional study and represents Ohana's most conventional writing for the keyboard, making no more unusual demands on the player than the most secure of virtuosic, passage-work techniques. The work is sub-divided into four movements, Allegretto con moto, Vif, Andante, and Animé, and has the character of a keyboard toccata. Varying types of broken-chord texture predominate in each movement and are alternated with monodic sections of single melodic lines. In this way Ohana achieves his objective to write a work in which no note sounds with any other, unless in unison. Consequently the sostenente pedal is used very sparingly, thus 
resulting in the work's characteristically dry sound-texture. In this way, the Sonatine represents a study in monody as the means of generating musical material. This concept is developed in later works to become one of the most important and far-reaching processes in Ohana's mature musical language, although subject to far greater subtlety of expression than in this early piano work. The first movement is a basic ternary structure, with the opening material appearing in varied form in the final section. The incisiveness of the triple metre and syncopated rhythmic patterns recall the character of some Spanish dances, in particular the buleria and jota. It is the second movement of the Sonatine, however, which Ohana specifies as a jota, although the meter is changed from the more conventional $3 / 8$ to a $6 / 8$, unusual for this dance-type. ${ }^{18}$ Rhythmically, this movement is not unlike Falla's jota in the Siete Canciones Populares Españolas. The ensuing Andante represents an amalgam of the improvised 'debla' of the Cante Flamenco and the 'solea' of the Cante Jondo, with the piano's arpeggiations fulfilling the role of the vocal melisma. In the manner of improvised song, there are many changes and contrasts of tempo. The final Animé is the most rapid and virtuosic of the toccata-like movements. It returns to the lively dance-type rhythmic patterning with syncopated accentuations and hemiola alternations of $3 / 8$ and $2 / 8$. Towards the end of the movement, two entries of a brief fugal exposition emerge but only as a humorous 'nose-thumbing' at conventional classical form; it disintegrates into monodic figurations of the opening section and it is a fugue intentionally 'mise à plat'.

Following the Sonatine Monodique Ohana composed seven concert works and three scores for incidental music all of which the composer chose to suppress. These works reveal an extension of compositional activity beyond writing for piano and included a concerto for brass, percussion and strings, as well as a Sarabande for two pianos rearranged for harpsichord and orchestra. ${ }^{19}$. The fact that he subsequently chose to withdraw or destroy these works suggests the composer recognised only his writing for solo piano as representative of his true line of musical development. The third 
piece of the Trois caprices was the second to be composed. Completed in 1948, the Paso was given its first performance together with 'Enterrar y Callar' at a concert of the Groupe Zodiaque in Paris on 12 June the same year, the composer's thirtyfifth birthday. The title makes reference to the dramatic scenes, or 'incidents' of Spanish popular theatre and most importantly in this context, to the processions of Holy Week. Such holy processions, particularly in Andalusia are characterised by their solemn character and spontaneous expressions of intense emotion in the improvised Saetas. The musical character of this piece is predominantly declamatory, many of the melodic gestures recalling those of the Andalusian Cante Jondo. With many inventive effects of resonance achieved through the use of both sostemuto and sostenente pedals sustaining chords under expressive, melismatic melodic material, there is much in this piece that echoes certain passages in FêteDieu à Seville from Albeniz's Ibéria (Figure 2). In his own researches into Spanish and particularly the Andalusian Cante Jondo, Ohana suggested that the Saeta itself originated in Seville. Clearly the deeper explorations into the melodic character of popular Spanish music witnessed in the Paso pave the way for Ohana's more extensive Iberian essay, the setting of Lorca's Llanto por Ignacio Sanchez Mejias which draws much from the singing style of the musicians of the Andalusian Cante Jondo.

The second of Ohana's Trois Caprices was the last to be composed. 'Hommage à Luis Milán' was completed in 1954, the Trois Caprices finally coming together as a set in 1955 (Ohana recorded them the same year.) This short piece continues the Spanish associations of the other Caprices but draws its inspiration instead from Spanish art music and shows some of the greatest harmonic inventiveness of any of his early works. It is intended as a homage to the early sixteenth century Aragonese composer of music for the vihuela and lute, Don Luis de Milán, himself renowned for unconventional harmonies. The short piece represents the first appearance of Ohana's more radical keyboard writing; the pianist is required to use a felt-covered ruler (dimensions specified in the 
score) to depress certain chord-clusters on white keys, these being sustained by the sostemito pedal. Against this harmonic background are juxtaposed contrasting chord-aggregates, the harmonic resonance and interference being cleared with each new chord by changes of the sostenente pedal. Also unmetred, this short piece reveals the beginnings of Ohana's harmonic process of intervallic differentiation where chord-aggregates based on tritones and minor seconds are juxtaposed with chord-aggregates based on perfect intervals and major seconds.

While Ohana's contribution to the repertoire of the piano spans most of the years of his creative life and does reflect much of his personal development as a composer, his writing for the instrument was not continuous. It has already been shown that the Trois Caprices were composed over a ten year period and it was nearly a further twenty years before the completion of his next important works for piano, Sorôn-Ngô and the 24 Préludes. It is sometimes suggested that composers who are themselves pianists often have to turn away from writing for their own instrument during the period when they are in the process of developing their musical language. The very nature of the problem of writing for the piano necessitates the composer to answer certain questions about his own musical vocabulary in order to be able to simplify and condense his language onto one instrument. Witness the work of Lutoslawski who for many years stated that the nature of his aleatory counterpoint was unsuited for the medium of the piano. Only in 1988, after his musical language had undergone further change did he complete his long awaited Concerto for Piano and Orchestra. Messiaen, conversely had precisely catalogued many of his compositional techniques in Techniques de mon Langage Musical and was, as a consequent, able to begin his large piano works comparatively earlier in his composing life. During the period which followed the completion of the Trois Caprices, Ohana's compositional language began to undergo a period of transition and as a consequent it is interesting to observe that he withdrew from composing for the piano purely as a solo instrument. 
Commissioned by the ORTF for the centenary celebration of Debussy's birth, Tombeau de Claude Debussy for soprano, zither, piano and orchestra clearly indicates Ohana's firm alignment with the French tradition. Composed during his stylistically transitional years of the early 1960s, the influence of Spanish music is less conspicuous than in Ohana's earlier scores, having become part of an integral, more homogenous musical language. The score, according to the composer's own preface, draws much of its musical material from Debussy, in particular the piano Préludes and Etudes, as well as from certain sections of En Blanc et Noir and Pelléas et Mélisande. (Discussion of Ohana's process of allusion and paraphrase does not come within the scope of the present article. ${ }^{20}$ ) The instrumentation of this seven movement work reveals the particular timbre that is characteristic of the composer from this date; not only does he make use of the soprano, zither and piano, but the orchestra comprises strings, wood-wind soloists, horn and trumpet, and a large percussion section (requiring six players) which itself is sub-divided into pitched and unpitched metal, wood and skin. Although the piano is one of the three named solo instruments, it in fact plays more of a hybrid role, for much of the time underpinning and doubling much of the orchestral texture (indeed the piano doubles with celesta), only occasionally emerging as a soloist. The piano only really takes centre stage once in Tombecu de Claude Debussy; the central section of the central fourth movement, 'Autre Soleils', is a prolonged cadenza for solo piano, significantly occupying a pivotal position in the work as a whole. Arguably more interesting than the use of the piano is the use of the two other soloists in this work. For the first time Ohana abandons text and, in the manner of a quasi-improvised vocalisation, the soprano line functions more as an additional texture rather than as a dramatic soloist, appearing in only three of the seven movements (I, IV, VII). Following experimentations in earlier works, Ohana extends the expressive range of the vocal line though the incorporation of certain micro-intervals, not quarter-tones but the more unusual third-tones. It is for this reason that he includes the 
zither, perhaps the most curious of all instruments to find in a modern orchestra, as it can easily be tuned to the scale of third-tone microintervals, itself based on the Debussian whole-tone scale. ${ }^{21}$ This enables Ohana to use micro-intervals harmonically, as well as melodically.

Ohana's mature musical language came to fruition in the middle 1960 s, crystallising in the composition of Signes, a chamber work completed in 1965 for flute (piccolo), two zithers (tuned chromatically and in third-tone microintervals), piano and percussion (four players). It is in this work where Ohana rediscovers the dramatic power of the piano as a soloist and where all the main features of his mature style are manifest for the first time, including the sections of layered, aleatory counterpoint which are still lacking in the stylistically transitional Tombeau de Claude Debussy. The composer himself recognised this work as a compositional milestone; Signes is the first of a series of works beginning with the letter ' $\mathrm{S}$ ' which, according to the composer, represents an esoteric association with the Greek 'sigma' symbolising 'evolution'. 22 This new, stylistic maturity is the result of the experimentations particularly of the early 1960s and reveals not only a less obvious Iberianism, but, as is characteristic for Ohana in his mature works, a virtual multi-culturism. In fact, far from being in any sense Spanish, as it at first assumed in so much of Ohana's work, Signes is intended as a Japanese landscape; many timbral allusions to oriental instruments achieved through the particular characteristics inherent in Ohana's own ensemble. In fact, the instrumental timbre of Signes (although not the delineation of pitch) has much in common with Boulez' Le Marteau sans Maitre. Perhaps not unlike many of the nature themes in Japanese poetry, Signes concerns an unusually descriptive, almost impressionistic, programme: the 'signs' of the title refer to the ciphers drawn in the score by the composer which are intended to suggest the contemplation of the life of a tree, the six movements representing, 'at night', 'alive with birds', drowned with rain', 'imprisoned in gossamer' (spiders' webs), 'beaten by the wind', 'burnt by the sun'. An ancient symbol, the image of the 
tree is rich in association, in particular with physical growth and maturation. ${ }^{23}$ In Signes, the suggestion is that Ohana's musical style, like the tree, will take root, grow and proliferate.

The multi-culturism of Signes is further underlined by the presence of, according to the composer, African and Afro-Cuban rhythmic patterns which become integral elements in Ohana's musical vocabulary from this work onwards. Although conspicuous throughout the score, these rhythms appear in many guises chiefly in the percussion (pitched and unpitched) and piano parts. They are heard in dramatic context in the tumultuous, fifth movement, 'beaten by the wind', in which the piano becomes a fully-fledged soloist (Figure 3 ). It is interesting to note that Ohana intended this movement as a commentary on Debussy's piano prelude Ce qu'a vu le vent d'ouest. ${ }^{24}$ With the exploitation of the almost pitchless and very percussive, lowest extremes of the piano register, the instrument is entirely percussive and drum-like, the effect of the movement being that of a frenetic, quasi-improvisatory rhythmic monody.

Completed one year after Signes in 1966, Synaxis is more of a concerto for orchestra and percussion than a true concerto for two pianos. As in Tombeau de Claude Debussy, the pianos play a hybrid role, sometimes acting as integral members of the instrumental ensemble, at other times emerging as soloists in their own right. One of their main functions is one of timbral contrast, as they are often juxtaposed against the large percussion section (6 players), thus creating a textural dialogue which seeks to explore and contrast the melodic and rhythmic capabilities of both instrumental types. For this purpose Ohana always includes pitched percussion, most notably a set of pitched toms, which are used melodically, as well as purely rhythmically. In this way, Synaxis extends the rhythmic and timbral processes beginning in the fifth movement of Signes. Also like Signes, the eight movements of Synaxis proceed without a break, but unlike Signes it is Ohana's first work to combine an interlocking arch-shape with the symmetrical structures already common in the works of his transitional period. The percussive possibilities of the human voice and the lyrical possibilities of 
percussion are recurrent themes in Ohana's mature music and, although there is no vocal part in Synaxis, this work is one of his first to explore these relationships. This is largely achieved thought the associations of the movement titles which refer to vocal forms of the Middle Ages, as well as of more ancient times. The title of the work itself is, according to the composer, a name given to primitive liturgy of the second century. ${ }^{25}$

Despite the apparent compositional and pianistic discoveries of Signes and Synaxis another four years elapsed before Ohana ventured into a composition for the piano without the support of an orchestra or instrumental ensemble. Even in this next work, Sorôn-Ngô, Ohana does not yet condense his writing onto a single instrument. It is Ohana's only work for two pianos. Composed to celebrate the twentieth anniversary of the Geneviève Joy and Jacqueline Robin Duo, Sorôn-Ngô received its first performance in July 1971 at the Festival of Aix-en-Provence. It is one of a group of works (and movements) incorporating the suffix 'ngo' in their title, others including T'Hâran-Ngô, Korôn-Ngô, Son Chango and Farân-Ngô. All these works are primarily concerned with different rhythmic procedures, as distinct and independent from melodic or harmonic ones, and aim, according to the composer, to evoke an atmosphere of frenetic, tribal ritual: "one find the suffix 'ngô' in a certain number of works designating dances and sometimes the instruments accompanying such dances, which are of African origin. Such works are popular in Andalusian art; the Tango, Zorongo, Fandango and even the Bongo.... The vocable 'ngo' seems above all to characterise incantatory dances stemming from ancient tribal ceremonies." ${ }^{26}$ Incorporating Ohana's process of combining and superimposing layers of independent counterpoint without precise vertical co-ordination, the work involves controlled elements of aleatory techniques. Such aleatorism does not affect the overall structure of the work which, although sectional, is strictly controlled by the composer. The work explores the many effects of resonance resulting between the two instruments. Ohana notates precise use of both sostemuto and sostenente pedals, central in obtaining 
resonances (as weil as sections without pedal) and felt-covered rulers are required to depress large chord clusters (black or white keys) silently, against which loud, staccato chords are juxtaposed.

The 24 Préludes represent Ohana's first real work for solo piano since 1954. Completed in 1973, they are the culmination of a period of compositional gestation of more than twenty years and are a virtual catalogue of his mature musical language. Composed in homage to Chopin, the final note of Ohana's cycle is the same low ' $\mathrm{D}$ ' concluding that of Chopin, and are intended to be performed without a break. Some of Ohana's Préludes are quite short, miniatures serving to introduce longer pieces to follow. Numbers 16 and 17 are paired in this way. Other Préludes are more declamatory in form and content (Nos.14 and 15). Despite these associations with Chopin, many of Ohana's Préludes reveal a close affinity with the pianistic sound-world of Debussy. The fifth is one of the first to bear witness to this close relationship. Recalling 'Brouillards', in what is almost a cliché of 'impressionist' pianism, a sustained but quiet melodic line emerges from a pianissimo soundmass (Figure 4). This texture is not unlike many similar passages in Debussy's Etudes. The central section of Prélude No.13 is also very evocative of Debussy; not only are black and white keys juxtaposed (black in the left hand, white in the right) in a manner recalling sections of the Etudes 'Pour les huit doigts' and 'Pour les degrés chromatiques', but the short descending white-key figures of the right hand are strikingly similar to the 'five-finger' groups in Debussy's Etude 'Pour les cinq doigts'. Ohana's eighth Prélude is Debussyist in that its inspiration is drawn from nature, a feature of many of Ohana's works. While the wind is evoked in the fifth movement of Signes, for example, the eighth Prélude is suggestive of rain. It exploits the highest registers of the piano in veritable cascades of tremolos, glissandi, clusters and repeated notes. Such impressionist pianism is a clear extension of textures and techniques found in Liszt's Jeux d'eau à la Villa d'Este, Ravel's Jeux d'eau and Debussy's Jardin sous la pluie. ${ }^{27}$ This same Prélude involves certain ad libitum techniques characteristic of Ohana's mature mu- 
sical language; the performer is required to 'improvise' on given note patterns for an unspecified length of time also to be determined by the player. Like the majority of the 24 Préludes, the eighth is freely composed without recourse to measured bars, the purpose being to recreate the spontaneity of improvisation within the confines of a composed and therefore 'fixed' score.

Like Chopin's preludes, and to a certain extent those of Debussy, Ohana's explore specific compositional and pianistic problems, Indeed, like those of Chopin, many can be described in terms of their particular, overriding character; one a quasi-etude, another a nocturne, another compositional study, and so on. So focus on certain intervals: for example fourths in No.8; seconz and their invertional equivalents sevenths and ninths, in Numbers 10 and 12; tenths in No.11. Others focus on pianistic problems trills (No.7); glissandos (No.14), clusters (No.14), tremolos (Nos.8 and 22); legato playing (Nos.1 and 5); chords (No.15); superimposed aleatory counterpoint (No.19); rhythmic canon (No.20); the sostemuto pedal (Nos.1, 18 and 24). Throughout the cycle, Ohana carefully notates the use of all three pedals to achieve dry or muted percussive effects with the una corda, as well as precise resonances with the sostemuto and sostenente pedals as in Prélude No.18. In many cases effects of resonance are combined with silent depressing of the keys. Virtuosity is demanded in all of the Préludes .

Although Ohana's musical language is profoundly indebted to the sound-world of Debussy, it would be wrong to suggest that it was merely derivative or that this was the predominant character of Ohana's pianism. Just as crucial in Ohana's view of the piano is its percussive nature: "I would say that since Debussy's concept there has been Stravinsky and Bartók which are rather percussive concepts of piano playing and I myself, being quite fond of percussion, was very attracted to that aspect of piano playing. I think percussion is one of the most important means of expression of our music, the music of our time, which has, willingly or unwillingly, been deeply influenced by jazz and by the Negro playing 
of piano percussion which itself comes from Africa. There's Cuban folk-music which is African too." 28

Since Signes, Ohana's writing for the piano has continually sought to explore a rich variety of percussive techniques: using the extremes of the piano to emphasise rhythm and timbre rather than precise pitch; using the una corda while playing forte to achieve a dull, drum-like sound without sustaining pedal; evolving a complex vocabulary of African, Afro-Cuban and derived rhythmic patters. In an examination of any of Ohana's writing for percussion, which is itself extensive, it can be seen that he also considers these instruments capable of an almost lyrical expressiveness. His equating of the percussion with the human voice is a great insight not only to his writing for the piano, but to his mature compositional style in general: "I think percussion is the cousin of the human voice, because a human voice is very often tempted to be percussive and to imitate percussions of a rather subtle nature. And both the percussion and the human voice can escape very easily the diatonic frame and diatonic cadences and chords. I think the future of music is in fact contained mostly in the voice and in percussion...as a way of expression in its own right." 29

Throughout his composing life, Ohana revealed a predilection for the concerto, not in any traditional formal sense, but in the opportunities it presents for the opposition and juxtaposition of a solo player with a larger group. He composed more than seven concertos, those he allowed to remain in his catalogue being: Sarabande for Harpsichord and Orchestra (1950), Trois Graphiques for guitar and orchestra (1957), Synaxis (1966), Chiffres de Clavecin (1968, concerto for harpsichord and orchestra), Anneau du Tamarit (1976, concerto for cello and orchestra), Concerto pour Piano et Orchestre (1981), Concerto pour violoncelle et Orchestre (1990). The Piano Concerto represents a return to Iberian sources as it seeks to explore the expressive capabilities of the soloist through recourse to the Andalusian Saeta. In his typically multicultural way, Ohana juxtaposes and alternates these incantatory melodies with contrasting sections where the harmonic and rhythmic 
material owes much to the masters of keyboard jazz. This is not the first time Ohana has made recourse to harmonic colours of jazz; the ninth of his 24 Préludes is dedicated to the memory of Fats Waller and Count Basie. One of the most striking features of the Piano Concerto is the dramatic juxtaposition of measured material in the orchestra against un-measured quasi-improvisatory material performed by the soloist. The Concerto is a single movement of sectional form.

Like Debussy's Etudes, Ohana's twelve Etudes d'Interprétation composed between 1982 and 1985, are divided into two books of six. The last two of the second book, 'Sons confondus' and 'Imitations-Dialogues', are, however, scored for piano and percussion and represent a logical development of the composer's fascination for exploring the lyricism of percussion and rhythmic percussiveness. Furthermore, one of the Etudes d'Interprétation in Book Two, 'Septièmes', is dedicated to the memory of Béla Bartók. As the title of the work as a whole suggests, these studies are exercises for the performer but equally compositional exercises in sonority. Like many of the 24 Préludes, they explore certain pianistic problems, although on a much larger scale. In no way miniatures, each of the twelve etudes is substantial. The fourth émde of the first book is a study for the left hand, 'Main gauche seule' (dedicated to the memory of Maurice Ravel), while the sixth is a study for the so-called 'third' pedal. 'Quintes', also from Book One, demands the greatest security in legato playing and involves the playing of fifths, and compound fifths, in both hands simultaneously. In character and atmosphere, as well as harmonic colour, the introvert nature of this etude makes it a close sibling to Debussy's Etude pour les quartes. The titles of Ohana's etudes indicate the compositional problem which serves as a basis for the study: 'Cadences libres' is largely unmetered and suggests improvisation; 'Contrepoints libres' is also unmetered but explores the problems of superimposed layers of independent, melodic counterpoint; 'Mouvements parall_les' contrasts differing characters of parallel movement, at once slow with each hand at the respective 
extremes of register, then a rapid perpetuo-moto with the hands closer together. The incorporation of repeated notes in the rapid section of 'Mouvements parallèles' adds to the high virtuosic demands on the performer. 'Agrégats sonores' is a deceptively simple study in melodic expressiveness. Four of Ohana's Etudes are constructed around certain intervals: 'Quintes', 'Septièmes', 'Secondes', 'Neuvièmes'. It is interesting to note that these are precisely the intervals which do not appear in Debussy's Etudes. Significantly Ohana considered his Etudes d'Interprétation more accessible than the 24 Préludes, suggesting that they be studies prior to Préludes. Although both works demand the virtuosic, technical security, the suggested accessibility of the Etudes may be due to their greater length which allows the pianist more time to focus on each compositional and technical problem. One of the greatest performing problems of the 24 Préludes is due simply to the length of the whole cycle combined with the mosaique-like structure of the often quite short, individual Préludes

During the 1980s Ohana planned and began work on another series of piano studies which he entitled Etudes d'Initiation. These short studies were intended as quasi-pedagogical works to encourage and prepare young student pianists for both the musical and technical demands of performing contemporary music. Sadly this project was never completed.

While Maurice Ohana's contribution to the piano repertoire is itself substantial and original, it is all the more remarkable that this was achieved against a background of prolific production in all genres. In addition to his concertos, he completed four operas, music-theatre and non-dramatic choral works and contributed two large-scale works to the orchestral repertoire. He composed for a variety of smaller ensembles and made a significant contribution to the repertoire of other solo instruments including the cello, guitar and harpsichord. While a significant number of composers who adopted and adapted serial principles in the early post-war years have since been noted for a relatively small catalogue of works, it is perhaps not insignificant that a composer who throughout his 
life was renowned for his individualism would appear to have found it comparatively easy to be prolific.

\section{NOTES}

1. Maurice Ohana was born a British subject (his father took British nationality in 1894) and thus served with the British Army during the 1939-1945 War. He saw active service in Madagascar, Kenya, Greece, and Italy and was commissioned in 1942 holding the badge of the Intelligence Corps.

2. Since Maurice Ohana's death on 13 November 1992, it has come to light that, due to a notable superstition surrounding the number 13, he successfully suppressed information concerning his actual year of birth. Contrary to all publications appearing before Ohana's death (including some of my own), his date of birth was not 1914 but 12 June 1913 . He was thus 79 when he died.

3. Caroline Rae: 'Debussy et Ohana: Allusions et Réferences', Les Cahiers Debussy no.17-18, 1993-94, p. 105

4. Conversations of Debussy with Ernest Guiraud collected by Maurice Emmanuel, presented and with commentary by Arthur Hoérée in AvantScène Opéra, no.11, sept-oct. 1977 p.144 and reproduced in English translation in E. Lockspeiser, Debussy his Life and Mind, vol. I, (London, 1962) pp.206-208.

5. "Les Cahiers de la Petite Dame", Cahiers André Gide, no.7, p. 159. The correspondence between Gide and Ohana has been collected and edited by Francis Bayer and is reproduced in Bulletin des Amis d'André Gide no.71 (juilliet 1986) vol XIV-XIX. See also 'André Gide et Maurice Ohana' in La Revue Musicale, no.391-393, (Paris, 1986) pp.161-169.

6. The author's conversations with the composer in Paris 1982-1987 sec Caroline Rae: The Music of Maurice Ohana, Doctoral Thesis University of Oxford, 1989.

7. 'Ohana on Ohana: an English Interview' with Richard Langham Smith, Contemporary Music Review, Volume 8, Part 1 (1993), p. 124.

8. Ohana's father ran his own business in shipping and export which necessitated the move of his family to Casblanca in 1900.

9. Caroline Rac: The Music of Maurice Ohana, Doctoral Thesis University of Oxford, 1989, p.4.

10. The author's conversations with the composer in Paris 1982-1987.

11. 'Ohana on Ohana: an English Interview' with Richard Langham Smith, Contemporary Music Review, Volume 8, Part 1 (1993), p. 128.

12. ibid. 
13. Pierre Ancelin: 'Entretein avec Maurice Ohana', Lettres françaises (September 1964).

14. Caroline Rae: 'Maurice Ohana: iconoclast or individualist ?' The Musical Times (February, 1991), pp.69-74.

15. The Groupe Zodiaque was founded in 1947 by Maurice Ohana, Alain Bermat and Pierre de la Forest-Divonne. They were later joined by Stanislas Skrowaczewski and Sergio de Castro.

16. BBC Radio 3: 'Music Weekly' (1984) Recorded Interview with Michael Oliver.

17. ibid.

18. M. Ohana: 'Notes du quelques formes du folklore espagnole', composer's manusript .

19. Caroline Rae: The Music of Maurice Ohana, op.cit, cf. catalogue of works.

20. Refer. Caroline Rae: 'Debussy et Ohana: Allusions et Références', Les Cahiers Debussy No.17-18, 1993-94.

21. Ibid. p.114.

22. The 'Sigma' series comprises cleven works composed from 1965 to 1976: Signes, Synaxis, Syllabaire pour Phèdre, Sibylle, Silenciaire, SorônNgô, Stream, Sytres, Sarc, Sacral d'Ilx, Satyres.

23. Caroline Rae: 'Le Symbolisme du Mythe Européen dans l'Oeuvre de Maurice Ohana', Les Cahiers du C.I.R.E.M. No..24-25 (Tours, 1993), pp.115-130.

24. The author's conversations with the composer in Paris 1982-1987.

25. M. Ohana: reproduced by C.Prost in La Revue Musicale No.391-393 (Paris, 1986), p.202.

26. M.Ohana: introduction for a performance of Sorôn-Ngô reproduced by C.Prost,op.cit., p. $2(7$.

27. Caroline Rae: 'Debussy et Ohana: Allusions et Réferences', Les Cahiers Debussy No.17-18, 1993-94, p.115.

28. 'Ohana on Ohana: an English Interview' with Richard Langham Smith, Contemporary Music Review, Volume 8, Part 1 (1993), p. 125.

29. Ibid.

Dr. Caroline Rae is a pianist and lecturer in music at the University of Wales, Cardiff. 
'Enterrar y Callar'
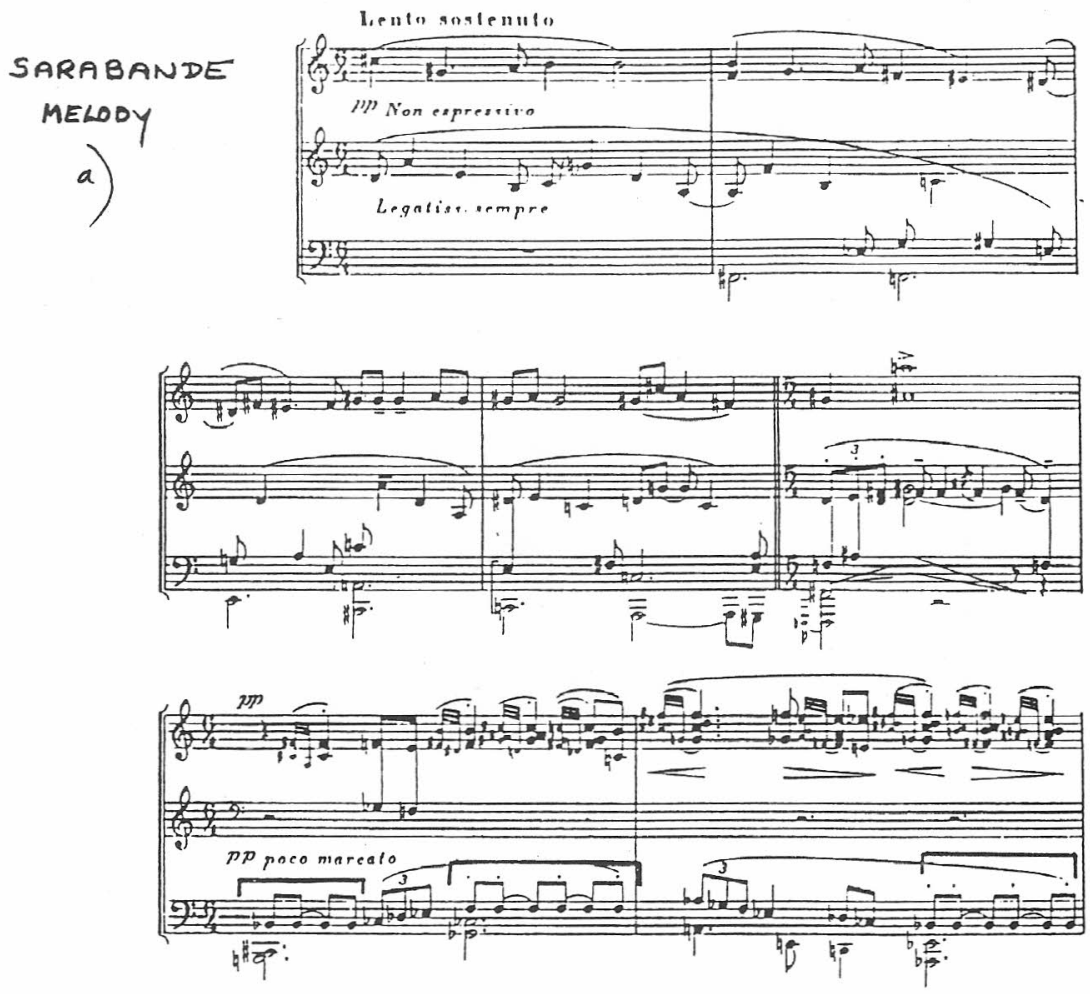

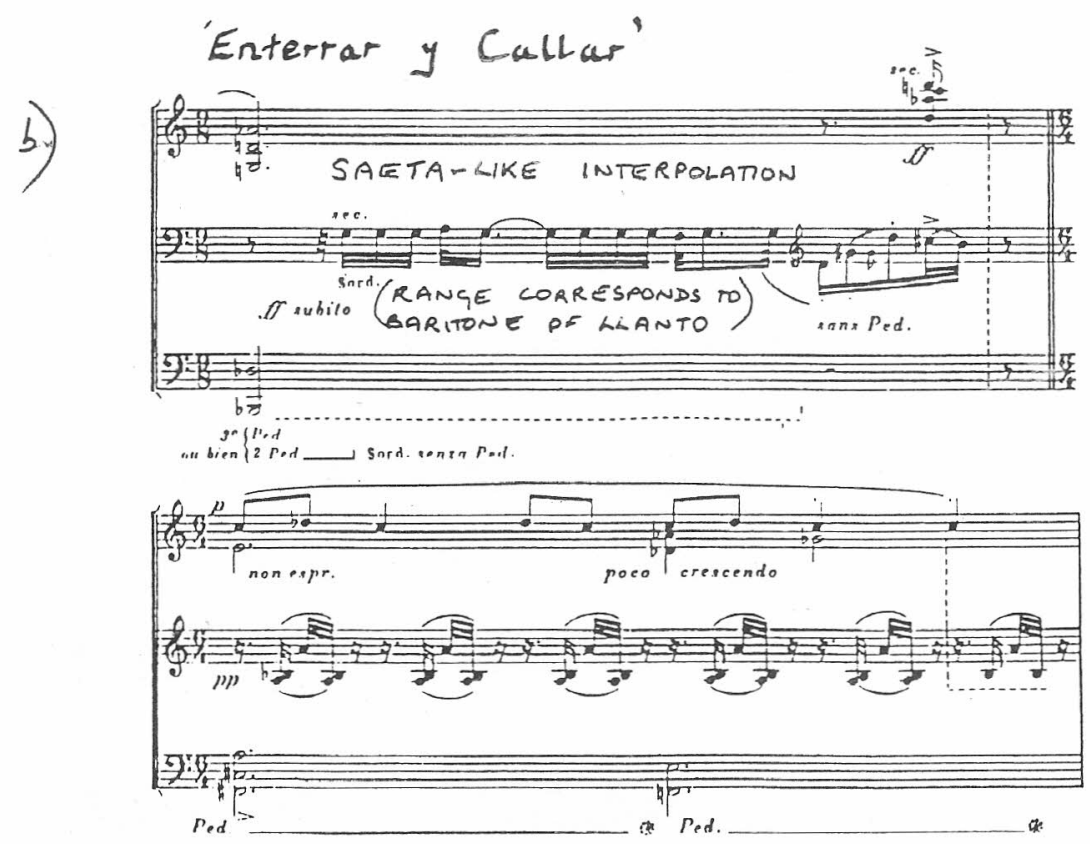

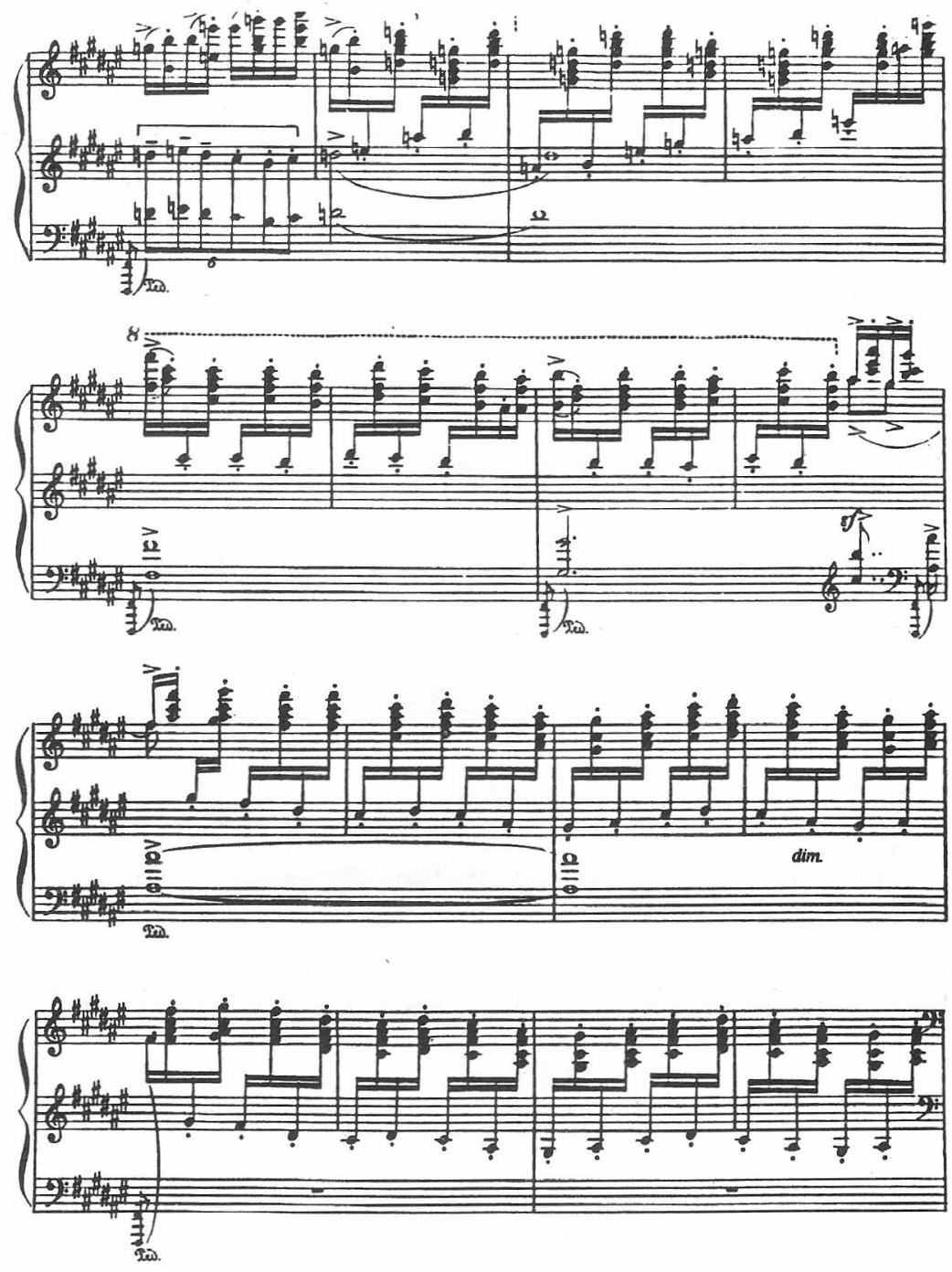

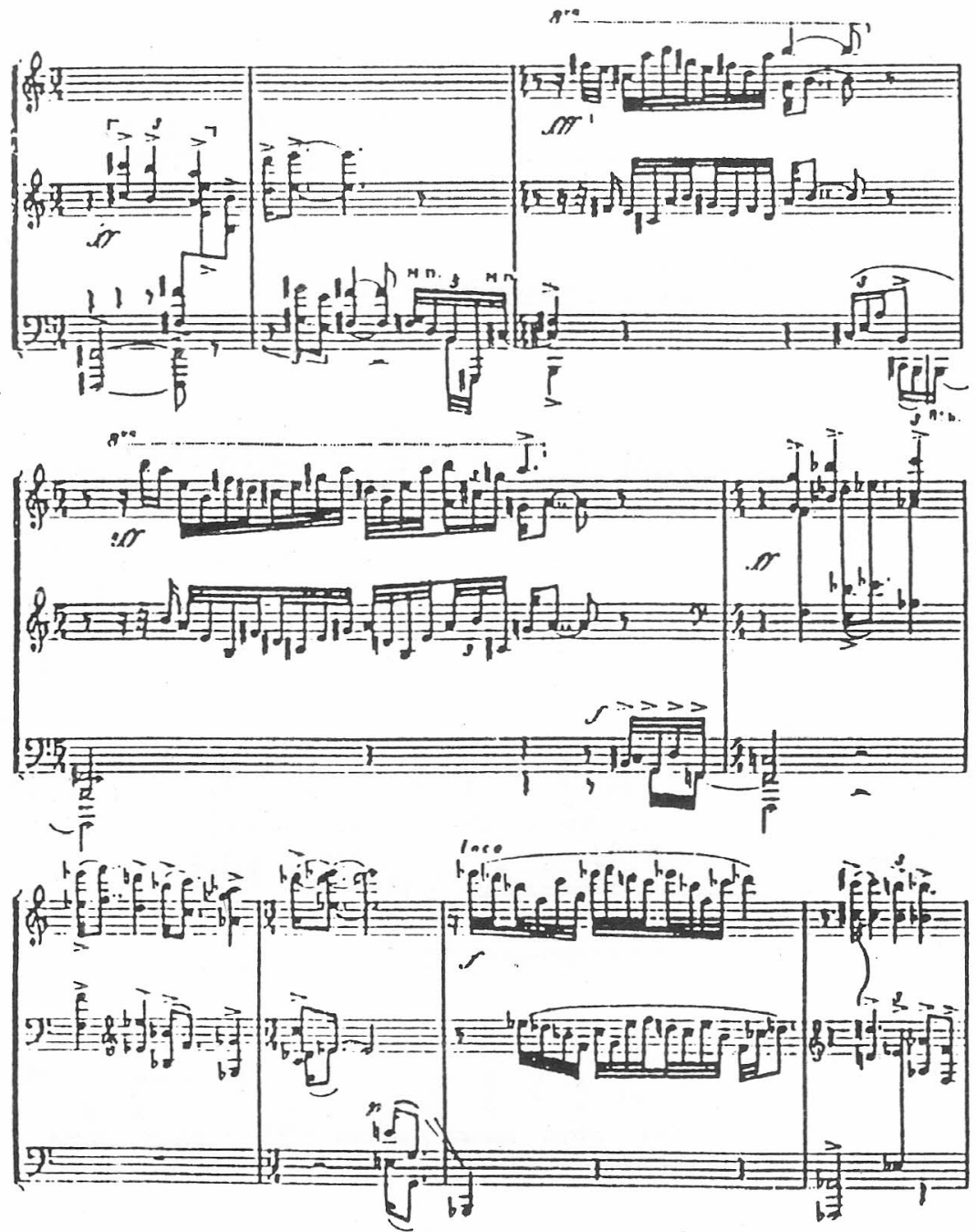

'PASO' - TROIS CAPRICES NO. 3 


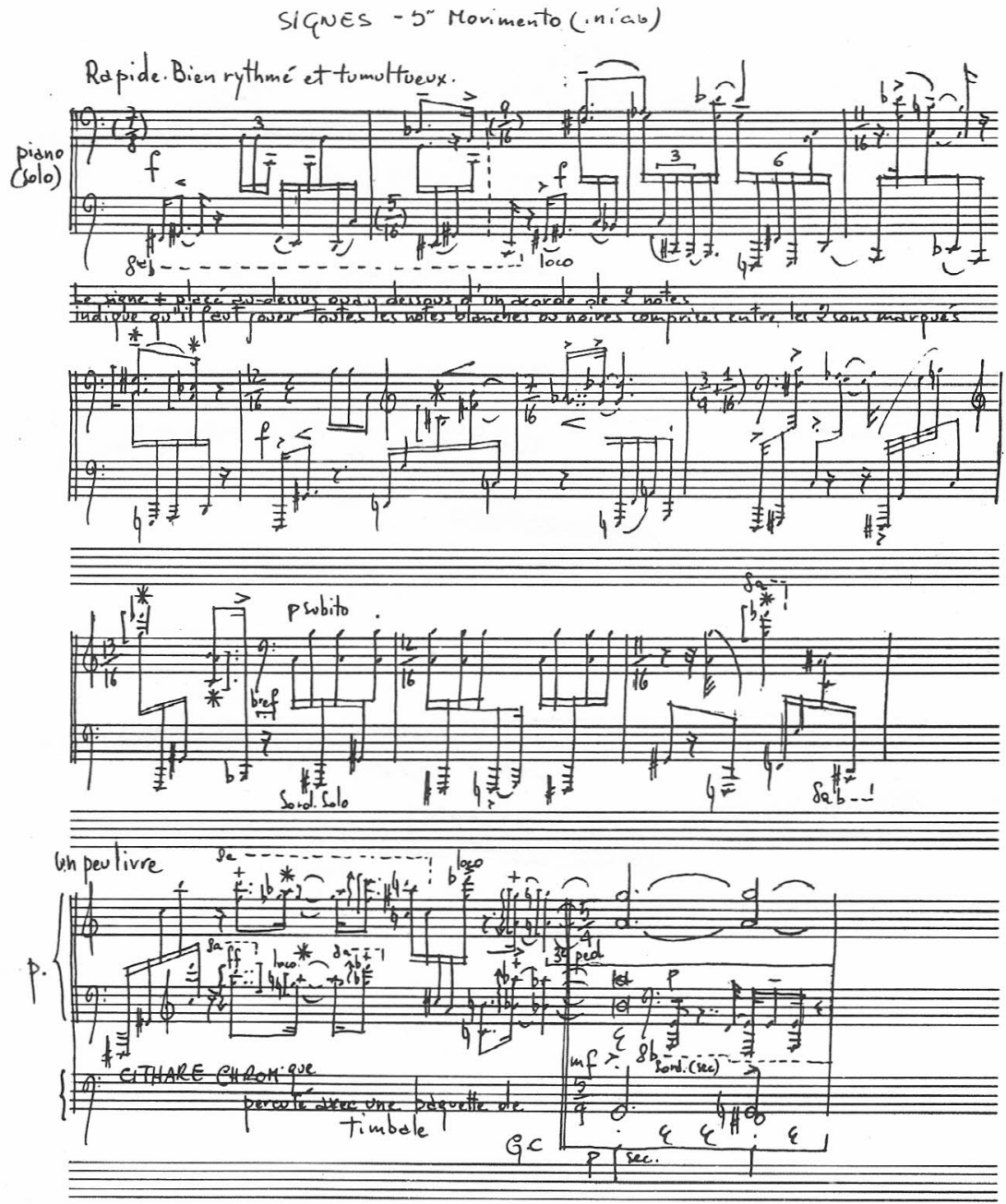


74 Revista Música, São Paulo, v.6, n.1/2:44-74 maio/nov. 1995

5. Pas trop vite, ègal

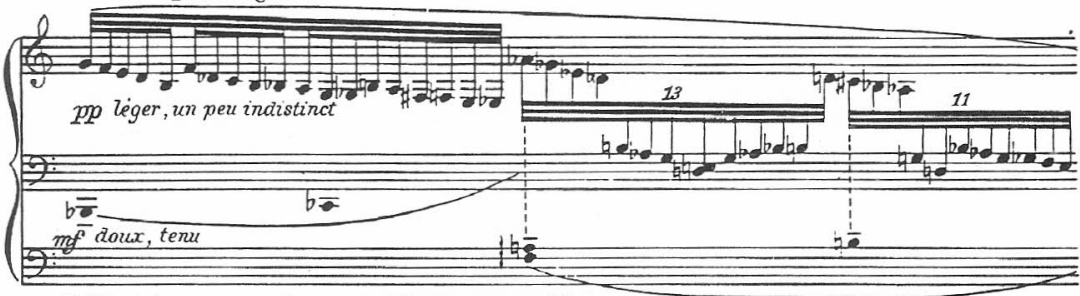

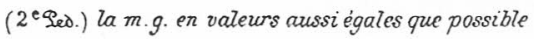
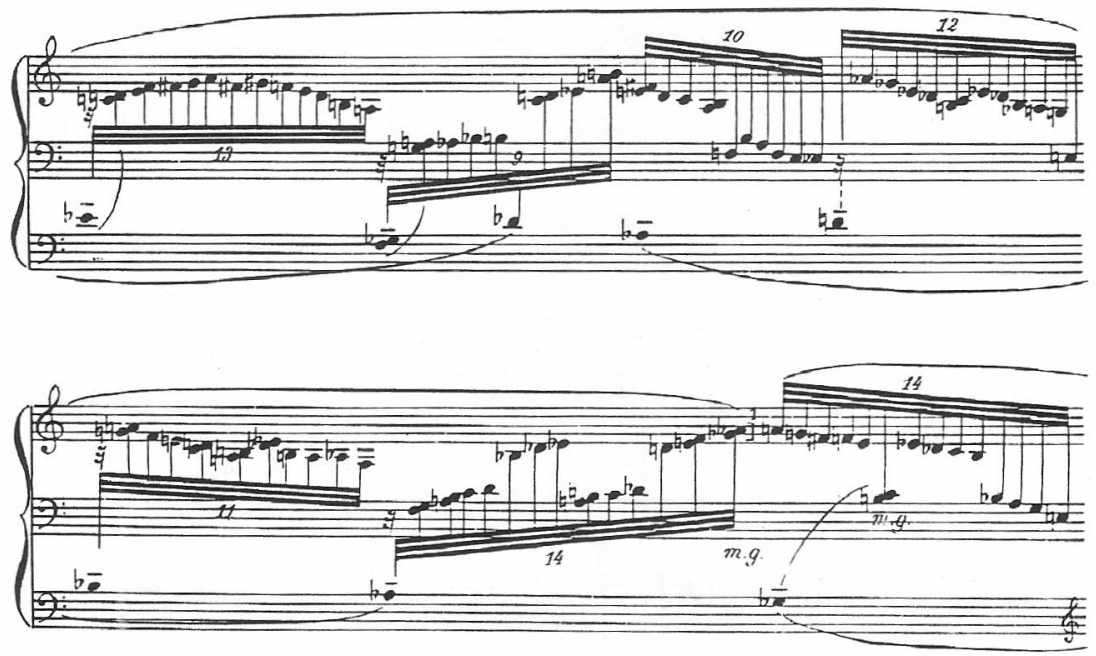

J.J. 909 